\title{
Age constraints on the Late Cretaceous alkaline magmatism on the West Iberian Margin
}

\author{
Rui Miranda a,b,d,*, Vasco Valadares ${ }^{\text {c,a }}$, Pedro Terrinha ${ }^{\mathrm{c}, \mathrm{b}}$, João Mata ${ }^{\mathrm{a}, \mathrm{d}}$, Maria do Rosário Azevedo ${ }^{\mathrm{e}}$, \\ Miguel Gaspar ${ }^{\mathrm{a}, \mathrm{f}}$, José Carlos Kullberg ${ }^{\mathrm{g}}$, Carlos Ribeiro ${ }^{\mathrm{h}}{ }^{\prime}$ \\ a Fac. de Ciências da Univ. de Lisboa, Depto. Geologia , Campo Grande, 1749-016 Lisboa, Portugal \\ ${ }^{\mathrm{b}}$ LATTEX, IDL, Univ. de Lisboa, Campo Grande, 1749-016 Lisboa, Portugal \\ ' INETI, Depto. Geologia Marinha, Estrada da Azambuja, 2720-866 Amadora, Portugal \\ ${ }^{\mathrm{d}}$ Centro de Geologia da Univ. de Lisboa, Campo Grande, 1749-016 Lisboa, Portugal \\ ${ }^{\mathrm{e}}$ Depto. Geociências da Univ. de Aveiro, Santiago Campus, 3810-003 Aveiro, Portugal \\ ${ }^{\mathrm{f}}$ CREMINER, Campo Grande, 1749-016 Lisboa, Portugal \\ ${ }^{\mathrm{g}}$ Depto. Ciências Terra, Fac. Ciências Tecnologia., Univ. Nova de Lisboa and CICEGe Quinta da Torre, 2829-516 Caparica, Portugal \\ ${ }^{\mathrm{h}}$ Depto. Geociências Univ. Évora and Centro de Geofisica de Évora, Rua Romão Ramalho, 59, 7000 Évora, Portugal
}

\section{A R T I C L E I N F O}

\section{Article history:}

Received 21 November 2007

Accepted in revised form

13 November 2008

Available online 30 November 2008

\section{Keywords:}

Geochronology

Alkaline magmatism

West Iberian Margin

Late Cretaceous

\begin{abstract}
A B S T R A C T
The onshore sector of the West Iberian Margin (WIM) was the locus of several cycles of magmatic activity during the Mesozoic, the most voluminous of which was of alkaline nature and occurred between 70 and $100 \mathrm{Ma}$. This cycle took place in a post-rift environment, during the $35^{\circ}$ counter-clockwise rotation of Iberia and initiation of the alpine compression. It includes the subvolcanic complexes of Sintra, Sines, and Monchique, the volcanic complex of Lisbon and several other minor intrusions, covering an area of approximately $325 \mathrm{~km}^{2}$. Previous cycles were tholeiitic and transitional in nature, occuring around $200 \mathrm{Ma}$ and $130-135 \mathrm{Ma}$, respectively.

New LA-ICP-MS U-Pb, ${ }^{40} \mathrm{Ar} /{ }^{39} \mathrm{Ar}$, K-Ar and $\mathrm{Rb}-\mathrm{Sr}$ ages on several intrusions distributed along the onshore WIM are presented, which combined with previously published data allows us to constrain the duration of the Late Cretaceous alkaline cycle to circa $22 \mathrm{Ma}(94-72 \mathrm{Ma}$ ) and define two pulses of magmatic activity. The first one (94-88 Ma) occurred during the opening of the Bay of Biscay and consequent rotation of Iberia and clusters above $\mathrm{N} 38^{\circ} 20^{\prime}$. The second pulse (75-72 Ma) has a wider geographical distribution, from $\mathrm{N} 37^{\circ}$ to $\mathrm{N} 39^{\circ}$. This final pulse occurred during the initial stages of the Alpine orogeny in Iberia that led to the formation of the Pyrenees and Betics and to tectonic inversion of the Mesozoic basins.

Isotope and trace element geochemistry point to a sublithospheric source for the alkaline magmatism that clearly distinguishes it from the previous cycles which had an important lithospheric mantle component. Also, it allows the discrimination between the two different alkaline pulses in terms of trace element abundance and residual mantle minerology. It is speculated that these differences might be the result of distinct magma ascent rates due to either more or less favourable tectonic settings that avoided or allowed the interaction with metasomatized lithosphere and equilibration with $\mathrm{K}$ rich minerals like amphibole and/or phlogopite.
\end{abstract}

๑) 2008 Elsevier Ltd. All rights reserved.

\section{Introduction}

The onshore sector of the West Iberian Margin (WIM) was the locus of several cycles of magmatic activity during the Mesozoic. Occurrences related to the first two cycles display tholeiitic and transitional affinities (Martins, 1991; Martins et al., 2008) and ages around $200 \mathrm{Ma}$ (e.g. Dunn et al., 1998; Verati et al., 2007) and

\footnotetext{
* Corresponding author.

E-mail address: rmmiranda@fc.ul.pt (R. Miranda).
}

130-135 Ma (Ferreira and Macedo, 1979), respectively. The last cycle was the most voluminous, shows an alkaline nature, and took place between 70 and $100 \mathrm{Ma}$ (Ferreira and Macedo, 1979).

This cycle includes the NNW-SSE aligned subvolcanic complexes of Sintra, Sines, and Monchique, the volcanic complex of Lisbon and several other minor intrusions (Fig. 1). These rocks are discontinuously exposed from parallels $39^{\circ} \mathrm{N}$ to $37^{\circ} \mathrm{N}$ and cover an area of approximately $325 \mathrm{~km}^{2}$ (Fig. 1). With the exception of the Monchique alkaline complex, all the alkaline rocks were emplaced within the Mesozoic Lusitanian and Algarve rift basins, developed in relation to the opening of the Atlantic. 